\title{
ICHTHYOFAUNA OF THE ESTUARIES OF THE CRICARÉ RIVER: LENGTH-WEIGHT RELATIONSHIP
}

\author{
Ictiofauna dos estuários do Rio Cricaré: \\ relação peso-comprimento
}

\author{
Maurício Hostim-Silva', Arthur da Costa Lima', Ana Carolina dos Passos ${ }^{2}$, \\ Henry Louis Spach ${ }^{3}$, Beatriz Fernanda Chincila Cartagena ${ }^{4}$, \\ Maíra Gnoatto Afonso², Junio Damasceno Souza²

\footnotetext{
${ }^{1}$ Programa de Pós Graduação em Biodiversidade Tropical - CEUNES/Universidade Federal do Espírito Santo, DCAB Rodovia BR 101 Norte, Km. 60, Bairro Litorâneo, S/N São Mateus - ES - CEP: 29.932-540. E-mails: mhostim@gmail.com and aclpesca@yahoo.com.br

2 Departamento de Oceanografia, Universidade Federal do Espírito Santo, Avenida F. Ferrari, 514, CEP 29075-910, Vitória - ES, Brasil. E-mails: anapassosooc@gmail.com and jdamascenobh@gmail.com

${ }^{3}$ Universidade Federal do Paraná, Centro de Estudos do Mar, Lab. de Ecologia de Peixes. Caixa Postal 61, CEP 83255-976. Pontal do Paraná, PR, Brasil. E-mais: henry@ufpr.br and mairagafonso@gmail.com

${ }^{4}$ Universidade Federal do Pará, Pós Graduação em Biologia Ambiental, Instituto de Estudos Costeiros. CEP 68600-000, Bragança, PA, Brasil. E-mail: bfccartagena@gmail.com
}

\begin{abstract}
This work presents the length-weight relationship of 25 fish species. The collections were carried out monthly from 2010 to 2011 using bottom trawls in the estuaries of the Cricaré River, Espirito Santo state, Brazil.

Keywords: fishes, coastal zone, Espírito Santo, Brazil

\section{RESUMO}

Este trabalho apresenta a relação peso-comprimento de 25 espécies de peixes. As coletas foram realizadas mensalmente de 2010 a 2011, utilizando redes de arrasto em estuários do rio Cricaré, Espírito Santo, Brasil.
\end{abstract}

Recebido em: 08/09/2017

Aprovado em: 15/03/2018

Publicado online em: 05/09/2018 


\section{Palavras-chave: peixes, zona costeira, Espírito Santo, Brasil. INTRODUCTION}

Length-weight relationship studies are used in fishery biology and in fish management because they permit weight estimates from length data and vice versa (Froese, 2006), comparison of spatial and temporal differences between populations or species, and determination of the condition factor (Viana et al., 2004). The parameters of this relationship ( $a$ and $b$ ) vary according to sex, body size, time and space, and variations in the population structure, food availability and fishery pressure may result in different length-weight relationships for the same species (Giacalone et al., 2010).

Considering the differences between the two estuaries, the objective of the present study was to identify possible changes in the relationship between length and weight of analyzed fish.

\section{MATERIALS AND METHODS}

\section{Study area}

The Cricaré River basin (northern Espírito Santo state) covers an area of about 13,500 $\mathrm{km}^{2}$ and is formed by the Cotaxé and Cricaré rivers, whose headwaters are found in Minas Gerais state, and meet in the municipality of São Mateus (Espírito Santo state). The Cricaré River flows north and drains into the Atlantic Ocean in the municipality of Conceição da Barra (Espírito Santo state) (Silva et al., 2005), while the Mariricu River (tributary of the Cricaré River) flows south and drains into the community of Barra Nova in the municipality of São Mateus, and forms the Barra Nova estuary. From this point, the two estuaries are clearly different: while the estuary to the north $\left(39^{\circ} 43^{\prime} 56.3^{\prime \prime} \mathrm{W} / 18^{\circ} 35^{\prime} 59.8^{\prime \prime} \mathrm{S}\right)$ is characterized by, mainly, red mangrove (Rhizophora mangle) and white mangrove (Laguncularia racemosa) forests (Silva et al., 2005), the estuary to the south (39 $\left.44^{\prime} 47.5^{\prime \prime} \mathrm{W} / 18^{\circ} 57^{\prime \prime} 05.3^{\prime \prime} \mathrm{S}\right)$ is formed by black mangrove (Avicennia schaueriana and A. germinans) forests in the upper course, mixed (R. mangle, L. racemosa and A. schaueriana) in the middle course and red ( $R$. mangle) in the lower course (Petrobras, 2007).

The estuaries of the Cricaré River present semidiurnal tides. The tidal mean was 0.78 $\mathrm{m}$ (mean interval between -0.04 and $1.51 \mathrm{~m}$ in the study period, Marinha, 2011). The climate is tropical wet, typical of intertropical regions, and a rainy period in the summer and dry period between April and September.

\section{Data collection}

The present work was developed in the estuaries of the Cricaré River (Conceição da Barra to the north and São Mateus/Barra Nova to the south) between September 2010 and October 2011. Three five-minute bottom trawls (with $2.8 \mathrm{~m}$ mouth opening by $3.90 \mathrm{~m}$ length) (mesh - body: $3.9 \mathrm{~cm}$ and bag: $2.2 \mathrm{~cm}$ ) (mean velocity: $2.9 \mathrm{~km} / \mathrm{h}$ ) were carried out monthly in each of the four areas chosen in each estuary.

All of the collected material was separated into plastic bags by site and sample, refrigerated and sent to the zoology laboratory of the Centro Universitário Norte do Espírito Santo (UFES) for identification and biometry. The identification of the fish was done to the lowest taxonomic level possible, based on Figueiredo \& Menezes (1978, 1980, 
2000), Menezes \& Figueiredo $(1980,1985)$, Barletta \& Corrêa (1992) and the consultation of specialists. The biometry was carried out using a digital scale $( \pm 0.01 \mathrm{~g})$ and a portable ichthyometer $( \pm 1.0 \mathrm{~mm})$.

\section{Data analyses}

The total length (TL) (mm) and weight $(\mathrm{W})(\mathrm{g})$ data of each fish with a capture number $\geq 5$ per species and estuary (Conceição da Barra and Barra Nova) were log-transformed in order to identify possible outliers. The constant of the linear equation $(a)$ and the allometric coefficient $(b)$ were obtained using linear regression analyses $(\log \mathrm{W}=\log a+b \log \mathrm{TL})$, with the TL and $W$ data log-transformed. The coefficient of determination $\left(r^{2}\right)$ was used as an indicator of the quality of the linear regression (Joyeux et al., 2009). Student's $t$-test $(p<0.05)$ was applied to verify if $b$ differed significantly from 3.0 (thus defining the type of growth: isometric or allometric), as well as detect significant differences between the coefficients of the 13 species common to the two estuaries (Le Cren, 1951, Zar, 1984).

\section{RESULTS}

A total of 25 species (13 occurring in both estuaries, nine exclusively in Conceição da Barra and three only in Barra Nova) was analyzed. As regards the species that occurred in both estuaries, the coefficient of determination $\left(\mathrm{r}^{2}\right)$ varied from 0.8183 (Cetengraulis edentulus) to 0.9930 (Bairdiella ronchus). In respect of the species exclusive to Barra Nova and Conceição da Barra, $\mathrm{r}^{2}$ varied from 0.8011 (Gobioides broussonnetii) to 0.9860 (Archosargus protabocephalus), and 0.6618 (Cyclichthys spinosus) to 0.9948 (Lutjanus jocu), respectively. The values of $b$ varied from 2.5742 in Centropomus parallelus to 3.5174 in Rypticus randalli for species common to both estuaries, from 2.4716 (C. spinosus) to 3.2429 (Stellifer rastrifer) for species present only in Conceição da Barra and from 2.0810 (Gobioides broussonnetii) to 3.2185 (Centropomus undecimalis) for species occurring only in Barra Nova (Tables 1 and 2).

Of the 13 species present in both estuaries, isometric growth was observed in seven species and positive allometric growth in one. On the other hand, Centropomus parallelus, Cetengraulis edentulus, Micropogonias furnieri, Rypticus randalli and Symphurus tessellatus presented different type of growth in each estuary (Tables 1 and 2). Of the three species caught only in the estuary of Barra Nova, one presented isometric growth, one positive allometric growth and one negative allometric growth (Table 2), while between nine species caught only in the estuary of Conceição da Barra, four present isometric growth, four negative allometric growth and one positive allometric growth (Table 1). The length-weight relationship data of Polydactylus oligodon are available only for Colombia.

Table 1 - Species and parameters of the length- weight relationships of fishes in the estuary of Conceição da Barra (Espírito Santo state). Data in bold refer to the species that occurred only in the estuary of Conceição da Barra (I: isometric; A+: positive allometric; A- : negative allometric).

\begin{tabular}{|c|c|c|c|c|c|c|c|c|c|c|}
\hline \multirow[b]{2}{*}{ Species } & \multirow[b]{2}{*}{$\mathrm{N}$} & \multirow{2}{*}{$\begin{array}{c}\mathrm{TL} \\
(\mathrm{mm}) \\
\text { min- } \\
\max \end{array}$} & \multirow[b]{2}{*}{ a } & \multicolumn{2}{|c|}{ TL 95\% } & \multicolumn{4}{|c|}{ TL 95\% } & \multirow[b]{2}{*}{ Grow } \\
\hline & & & & inf. & sup. & $\mathrm{b}$ & inf. & sup. & $r^{2}$ & \\
\hline Achirus declivis & 207 & $39-180$ & -4.9338 & -5.0384 & -4.8291 & 3.1170 & 3.0639 & 3.1702 & 0.9849 & I \\
\hline Achirus lineatus & 89 & $42-114$ & -4.8830 & -5.0909 & -4.6751 & 3.0870 & 2.9794 & 3.1946 & 0.9739 & I \\
\hline Bairdiella ronchus & 35 & $77-208$ & -5.2466 & -5.4470 & -5.0463 & 3.1660 & 3.0716 & 3.2604 & 0.9930 & I \\
\hline Caranx latus & 21 & $36-115$ & -4.2123 & -4.4973 & -3.9274 & 2.6796 & 2.5259 & 2.8333 & 0.9851 & A- \\
\hline
\end{tabular}


(continuation Table 1)

\begin{tabular}{|c|c|c|c|c|c|c|c|c|c|c|}
\hline Cathorops spixii & 65 & $112-250$ & -4.9498 & -5.2586 & -4.6410 & 2.9847 & 2.8465 & 3.1229 & 0.9673 & $\mathrm{I}$ \\
\hline Centropomus parallelus & 15 & $135-269$ & -4.0838 & -5.0035 & -3.1641 & 2.5742 & 2.1691 & 2.9794 & 0.9355 & A- \\
\hline Cetengraulis edentulus & 57 & $112-162$ & -5.8015 & -6.7204 & -4.8826 & 3.3441 & 2.9183 & 3.7700 & 0.8183 & I \\
\hline Citharichthys spilopterus & 113 & $72-165$ & -5.3909 & -5.6556 & -5.1261 & 3.1453 & 3.0125 & 3.2781 & 0.9520 & $\mathrm{I}$ \\
\hline Cyclichthys spinosus & 47 & $60-86$ & -3.1284 & -4.1073 & -2.1494 & 2.4716 & 1.9472 & 2.9959 & 0.6618 & A- \\
\hline Cynoscion acoupa & 59 & $51-287$ & -5.2511 & -5.4184 & -5.0839 & 3.0744 & 2.9946 & 3.1542 & 0.9905 & $\mathrm{I}$ \\
\hline Diapterus rhombeus & 1151 & $40-195$ & -5.1954 & -5.2759 & -5.1149 & 3.1717 & 3.1298 & 3.2136 & 0.9505 & $\mathrm{~A}+$ \\
\hline Lagocephalus laevigatus & 24 & 38-175 & -4.9403 & -5.4008 & -4.4798 & 3.1641 & 2.9173 & 3.4109 & 0.9698 & I \\
\hline Lutjanus jocu & 15 & $76-210$ & -4.6757 & -4.9554 & -4.3960 & 2.9612 & 2.8334 & 3.0889 & 0.9948 & I \\
\hline Micropogonias furnieri & 41 & $89-165$ & -5.1225 & -5.3066 & -4.9383 & 3.0552 & 2.9680 & 3.1424 & 0.9923 & I \\
\hline Mugil curema & 15 & $153-312$ & -4.2524 & -4.7333 & -3.7715 & 2.6709 & 2.4627 & 2.8790 & 0.9834 & A- \\
\hline Polydactylus oligodon & 21 & 112-192 & -5.2904 & -5.9335 & -4.6474 & 3.1228 & 2.8268 & 3.4188 & 0.9625 & I \\
\hline $\begin{array}{l}\text { Pseudauchenipterus } \\
\text { nodosus }\end{array}$ & 48 & $82-131$ & -4.8585 & -5.5232 & -4.1938 & 2.9579 & 2.6279 & 3.2880 & 0.876 & $\mathbf{I}$ \\
\hline Rypticus randalli & 25 & $105-164$ & -4.7132 & -5.4629 & -3.9636 & 2.9347 & 2.5841 & 3.2854 & 0.9287 & $\mathrm{I}$ \\
\hline Selene vomer & 23 & $42-163$ & -4.1467 & -4.4379 & -3.8554 & 2.6453 & 2.4946 & 2.7960 & 0.9845 & A- \\
\hline Sphoeroides testudineus & 237 & $54-238$ & -4.6457 & -4.8292 & -4.4622 & 3.0000 & 2.9158 & 3.0841 & 0.9545 & I \\
\hline Stellifer rastrifer & 79 & $53-163$ & -5.4199 & -5.5760 & -5.2638 & 3.2429 & 3.1635 & 3.3222 & 0.9885 & A+ \\
\hline Symphurus tessellatus & 45 & 99-195 & -5.8434 & -6.0924 & -5.5943 & 3.3399 & 3.2263 & 3.4535 & 0.9879 & $\mathrm{~A}+$ \\
\hline
\end{tabular}

Table 2 - Species and parameters of the length- weight relationships of fishes in the estuary of Barra Nova. Data in bold refer to the species that occurred only in the estuary of Barra Nova (I: isometric; A+: positive allometric).

\begin{tabular}{|c|c|c|c|c|c|c|c|c|c|c|}
\hline \multirow{2}{*}{ Species } & \multirow{2}{*}{$\mathrm{N}$} & \multirow{2}{*}{$\begin{array}{l}\text { TL (mm) } \\
\text { min-max }\end{array}$} & \multirow{2}{*}{ a } & \multicolumn{2}{|c|}{ TL 95\% } & \multirow[t]{2}{*}{ b } & \multicolumn{2}{|c|}{ TL 95\% } & \multirow{2}{*}{$\mathrm{r}^{2}$} & \multirow[b]{2}{*}{ Grow. } \\
\hline & & & & inf. & sup. & & inf. & sup. & & \\
\hline Achirus declivis & 120 & $43-110$ & -4.6898 & -4.9830 & -4.3967 & 2.9742 & 2.8156 & 3.1328 & 0.9212 & $\mathrm{I}$ \\
\hline Achirus lineatus & 32 & $40-75$ & -4.6491 & -5.1850 & -4.1131 & 2.9504 & 2.6473 & 3.2534 & 0.9295 & I \\
\hline Archosargus probatocephalus & 36 & $82-186$ & -4.8138 & -5.0784 & -4.5491 & 3.0572 & 2.9300 & 3.1843 & 0.9860 & I \\
\hline Bairdiella ronchus & 156 & $96-210$ & -5.2519 & -5.4338 & -5.0701 & 3.1543 & 3.0714 & 3.2373 & 0.9734 & $\mathrm{~A}+$ \\
\hline Cathorops spixii & 14 & $174-224$ & -5.3505 & -6.2760 & -4.4249 & 3.1357 & 2.7352 & 3.5363 & 0.9604 & I \\
\hline Centropomus parallelus & 94 & $99-419$ & -5.0998 & -5.2891 & -4.9106 & 3.0256 & 2.9419 & 3.1093 & 0.9825 & $\mathrm{I}$ \\
\hline Centropomus undecimalis & 31 & $167-417$ & -5.6747 & -5.1287 & -6.2207 & 3.2185 & 2.9920 & 3.4450 & 0.9668 & $A+$ \\
\hline Cetengraulis edentulus & 34 & $79-194$ & -6.0034 & -6.7315 & -5.2752 & 3.4353 & 3.0929 & 3.7776 & 0.9288 & $\mathrm{~A}+$ \\
\hline Citharichthys spilopterus & 24 & $65-180$ & -5.1418 & -5.5832 & -4.7005 & 3.0156 & 2.7997 & 3.2316 & 0.9744 & I \\
\hline Cynoscion acoupa & 32 & $36-414$ & -5.3044 & -5.5535 & -5.0552 & 3.0915 & 2.9676 & 3.2154 & 0.9886 & I \\
\hline Diapterus rhombeus & 407 & $50-192$ & -5.5794 & -5.6660 & -5.4929 & 3.3518 & 3.3100 & 3.3935 & 0.9840 & $\mathrm{~A}+$ \\
\hline Gobioides broussonnetii & 75 & 244-488 & -3.4728 & -4.0880 & -2.8577 & 2.0810 & 1.8391 & 2.3229 & 0.8011 & A- \\
\hline Micropogonias furnieri & 114 & $71-202$ & -5.4465 & -5.6588 & -5.2343 & 3.1933 & 3.0930 & 3.2935 & 0.9726 & $\mathrm{~A}+$ \\
\hline Rypticus randalli & 44 & $65-172$ & -5.9586 & -6.5171 & -5.4000 & 3.5174 & 3.2555 & 3.7794 & 0.9446 & $\mathrm{~A}+$ \\
\hline Sphoeroides testudineus & 182 & $50-231$ & -4.7864 & -4.9289 & -4.6439 & 3.0485 & 2.9807 & 3.1163 & 0.9775 & I \\
\hline Symphurus tessellatus & 19 & $117-150$ & -5.1831 & -6.1247 & -4.2415 & 3.0070 & 2.5586 & 3.4553 & 0.9217 & $\mathrm{I}$ \\
\hline
\end{tabular}

\section{DISCUSSION}

The results demonstrated high coefficients of determination for the fish in the estuaries of the Cricare River, which indicated the effective relationship between growth (length) and weight gain in these fish. However, it should be emphasized that the type of growth determined by the length-weight relationships referred to the site and time of the study, as a series of factors influenced the ontogenetic development of the ichthyofauna (Froese, 2006). Perhaps this was the reason C. parallelus, C. edentulus, M. furnieri, R. randalli and $S$. tessellatus presented a different type of growth in each estuary. This shows that although this study has covered, in every season, different oceanographic conditions and the composition of the vegetation of the estuaries of Barra Nova and Conceição da Barra, these factors were insufficient to demonstrate differences in the type of growth of seven 
species. Therefore, future analyses should consider other factors such as sex, gonodal maturity and diet (among others).

\section{REFERENCES}

Barletta, M. \& Corrêa, M.F.M. Guia para identificação de peixes da costa do Brasil, Editora UFPR, Curitiba, Brasil, 1992.

Figueiredo, J.L. \& Menezes, N. Manual de peixes marinhos do sudeste do Brasil. II. Teleostei (1). Museu de Zoologia, USP, São Paulo, 1978.

Figueiredo, J.L. \& Menezes, N. Manual de peixes marinhos do sudeste do Brasil. III. Teleostei (2). Museu de Zoologia, USP, São Paulo, 1980.

Figueiredo, J.L. \& Menezes, N. Manual de peixes marinhos do sudeste do Brasil. VI. Teleostei (5). Museu de Zoologia, USP, São Paulo, 2000.

Froese, R. Cube law, condition factor and weight-length relationships: history, metaanalysis and recommendations, J. Appl. Ichthyol., v. 22: p. 241-253, 2006.

Giacalone, V.M., D’Anna, G., Badalamenti, F. \& Pipitone, C. Weight-length relationships and condition factor trends for thirty-eight fish species in trawled and untrawled areas off the coast of northern Sicily (central Mediterranean Sea), J. Appl. Ichthyol., v. 26: p. 954-957, 2010.

Joyeux, J.C., Giarrizzo, T., Macieira, R.M., Spach, H.L. \& Vaske Jr., T. Length-weight relationships for Brazilian estuarine fishes along a latitudinal gradient. J. Appl Ichthyol., v. 25: p. 350-355, 2009.

Le Cren, E. D. The length-weight relationship and seasonal cycle in gonad weight and condition in the perch (Perca fluviatilis). J. Anim. Ecol. v. 20: p. 201-219, 1951.

Menezes, N. A. \& Figueiredo, J. L. Manual de peixes marinhos do sudeste do Brasil. IV. Teleostei (3). Museu de Zoologia USP, São Paulo, Brasil, 1980.

Menezes, N. A. \& Figueiredo, J. L. Manual de peixes marinhos do sudeste do Brasil. V. Teleostei (4), Museu de Zoologia USP, São Paulo, Brasil, 1985.

MARINHA. Tábua de marés. 2011. Disponível em: http://www.mar.mil.br/dhn/chm/ tabuas/index.htm. Acesso em: fev/2012.

PETROBRAS. Diagnóstico Ambiental: Atividade de Produção e Escoamento de Gás Natural e Petróleo do Campo de Camarupim, Bacia do Espírito Santo, pp. 283-284, 2007.

Silva, M. A. B., E. Bernini \& Carmo, T. M. S. Características estruturais de bosques de mangue do estuário do rio São Mateus, ES, Brasil. Acta Bot. Bras. v. 19: p. 465-471, 2005.

Vianna, M., Costa, F.E.S. \& Ferreira, C.N. Length-weight relationship of fish caught as by-catch by shrimp fishery in the southeastern coast of Brazil, Bol. Inst. Pesca, v. 30: p. 81-85, 2004.

Zar, J. H. Biostatistical analysis, $2^{\text {nd }}$ edition, Prentice-Hall, New Jersey, 1984. 